\title{
Reduction of the number of immunocompetent cells in the acute stage of herpes zoster
}

\author{
O. Baadsgaard ${ }^{1}$, R. Lindskov ${ }^{1}$, and C. Geisler ${ }^{2}$ \\ ${ }^{1}$ Department of Dermatology, Gentofte Hospital, Copenhagen \\ ${ }^{2}$ Department of Clinical Chemistry, The Finsen Institute, Rigshospitalet, Copenhagen
}

Summary. Circulating and in situ mononuclear cell subsets were phenotypically characterized during both the acute and convalescent phase of herpes zoster infections in 14 patients. In peripheral blood a significant reduction in the absolute number of Leu $4^{+} T$ cells, Leu $2 a^{+}$ suppressor/cytotoxic $\mathrm{T}$ cells, Leu $\mathrm{3a}^{+}$helper/inducer $\mathrm{T}$ cells, Leu $7^{+}$killer cells, and $\mathrm{B1}^{+} \mathrm{B}$ cells were found during the acute stage compared to convalescents and normal controls. In contrast no change in the absolute number of $\mathrm{MO}^{+}$monocytes was seen in the acute stage of the disease. During convalescence a return to normal values in the lymphocyte subsets and killer cells was seen within 1-2 months after the initial disease presentation.

In skin biopsy specimens from 4 of the 14 patients with active herpes zoster lesions the cellular infiltrate consisted of $T$ cells (Leu $4^{+}$) the majority being helper/ inducer $T$ cells $\left(\right.$ Leu $3 a^{+}$). Most of the cells expressed HLA-DR (Ia) antigens and were according to this in an activated state.

The observed changes in effector and regulatory cell numbers may have implications for the acquisition of Varicella-zoster virus infections, the immune deficiency state associated with the disease, and/or the immune response to resolve the infection.

Key words: Herpes zoster - Monoclonal antibodies $-\mathrm{T}$ cells $-\mathrm{B}$ cells - Monocytes

Varicella-zoster virus (VZV) belongs to the group of herpes virus. Primary infection causes chickenpox, but after the primary infection, the virus remains latent in the sensory ganglionic neurons until activation may

Offprint requests to: O. Baadsgaard, Assistant Professor, Department of Dermatology, Immunodermatology Unit, R5538 Kresge 1/0530, University of Michigan, Ann Arbor, Michigan 48109 , USA occur. The mechanism of reactivation is poorly understood; it occurs spontaneously, but it may be associated with malignant neoplasm irradiation and immunosuppressive therapy. During infection with VZV a depression of skin reactivity to tuberculin [7] as well as a depression in antigen stimulated blast transformation has been found [6].

To determine whether the observed viral associated immunodeficiency in patients with VZV insfections can be explained by changes in the number of cells contained within the different immunocompetent cell subsets, we have characterized these subsets in peripheral blood and skin biopsy specimens from patients with acute and convalescent stages of herpes zoster. We found that lymphocyte and killer cell numbers are indeed decreased during the acute phase of herpes zoster. Convalescence is associated with return to normal levels in 1 to 2 months after initial disease presentation.

\section{Material and methods}

Fourteen consecutive patients, 8 women and 6 men, admitted because of clinical herpes zoster were examined: Their mean age was 68 years (range 56 to 93 years). No patients had received immunologically active medication within a month before the study. Blood samples for immunological investigation were drawn both in the acute vesicular stage and in the convalescent phase, i.e., within 1 week and 6 to 9 weeks after onset.

In 4 of the 14 patients a 4-mm punch biopsy for immunohistopathological investigation was taken from a clinically active lesion.

Student's $t$-test for paired and nonpaired comparisons was used in the statistical evaluation.

The patients were their own controls but as an overall control 19 healthy volunteers with a mean age of 48 years were included.

\section{Immunofluorescence studies}

Mononuclear cells were isolated from freshly drawn, heparinized whole blood by Ficoll-Hypaque flotation (Lymphoprep), 
washed three times in Hank's balanced salt solution (HBSS), and resuspended in RPMI 1640 (Gibco) with $10 \% \mathrm{v} / \mathrm{v}$ newborn calf serum (Biocult). Separate tubes containing $10^{6}$ blood mononuclear cells were incubated with the monoclonal antibodies specified in Table 1 . A second incubation was done with F(ab)2 fragments of fluorescein isothiocyanate (FITC) labelled rabbit anti-mouse immunoglobulin absorbed with human immunoglobulin. The cells were washed in HBSS three times after each incubation. Fluorescence microscopy was performed on the same day as cell preparation using a Leitz-Ortholux microscope with epi-illumination. For each antibody and an unstained control, 200 cells were counted, and the proportion of cells with specific fluorescence was determined. The observer was blinded and was the same throughout. The absolute number of cells in each subpopulation was calculated from the white blood cell count and a routine leukocyte differential count.

\section{Immunohistochemical studies}

Biopsy specimens were snap-frozen in liquid nitrogen and stored at $-70^{\circ} \mathrm{C}$. Cryostat sections were fixed in acetone prior to staining.

Murine hybridoma monoclonal antibodies, with specificities summarized in Table 1, were used for immunophenotyping. The sections were incubated with monoclonal antibodies, washed in Tris-buffered saline, and labelled with peroxidase conjugated rabbit anti-mouse immunoglobulin (Dakopatts) diluted $1: 10$ with phosphate-buffered saline with $33 \%$ (v/v) normal human serum. The sections were thereafter washed, stained with 3ethyl-9-aminocarbazol and $\mathrm{H}_{2} \mathrm{O}_{2}$, counter-stained with Mayer's hematoxylin and mounted in Aquamont. Negative controls were performed by omitting the monoclonal antibodies.

\section{Results}

\section{Peripheral blood}

The absolute numbers of Leu $3 \mathrm{a}^{+}$, Leu $4^{+}$, Leu $7^{+}$, and $\mathrm{B}^{+}$cells were significantly reduced during the acute stage of herpes zoster when compared to con- valescence and normal controls $(p<0.01$; Tables 2 , 3 and 4). The absolute number of Leu $2 \mathrm{a}^{+}$cells during the acute stage were significantly reduced compared to convalescence ( $p<0.01$; Tables 2 and 3$)$, but not compared to normal controls $(0.2>p>0.1$; Tables 2 and 4). No changes were observed in the number of $\mathrm{MO}^{+}$cells in the acute stage when compared to levels obtained during the convalescent phase or from normal controls (Tables 2, 3 and 4). During convalescence the number of $\mathrm{MO}^{+}$cells increased, but not to statistically significant levels, neither when compared to values during the acute stage nor to the control values $(0.2>p>0.1 ;$ Fig. 1$)$. The decreased number of Leu $2 \mathrm{a}^{+}$, Leu $3 \mathrm{a}^{+}$, Leu $4^{+}$, Leu $a^{+}$, and

Table 1. Monoclonal antibodies used to identify cell membrane antigens in blood and cutaneous infiltrates

\begin{tabular}{|c|c|c|}
\hline $\begin{array}{l}\text { Monoclonal } \\
\text { antibody }\end{array}$ & Antigen or cell recognized & Source \\
\hline Leu $2 \mathrm{a}$ & $\begin{array}{l}\text { Suppressor/cytotoxic subsets } \\
\text { of T cells }\end{array}$ & $\begin{array}{l}\text { Becton } \\
\text { Dickinson }\end{array}$ \\
\hline Leu $3 a$. & $\begin{array}{l}\text { Helper/inducer subsets of } \\
\mathrm{T} \text { cells }\end{array}$ & - \\
\hline Leu 4 & $\begin{array}{l}\text { T-cell receptor all mature } \\
\text { circulating T cells }\end{array}$ & - \\
\hline Leu 6 & Langerhans cells in the skin & - \\
\hline Leu 7 & $\begin{array}{l}\text { Natural killer and killer cells; } \\
\text { subsets of Leu } 2 \mathrm{a}^{+} \text {cells }\end{array}$ & - \\
\hline $\mathrm{MO}^{\mathrm{a}}$ & Monocytes & Coulter Clone \\
\hline anti DR & $\begin{array}{l}\text { HLA-DR MHC class II } \\
\text { antigen }\end{array}$ & $\begin{array}{l}\text { Becton } \\
\text { Dickinson }\end{array}$ \\
\hline$B 1^{\text {a }}$ & B cells & Coulter Clone \\
\hline
\end{tabular}

a Only used in blood

Table 2. The number $\left(10^{9}\right.$ cells/1) of lymphocytes and monocytes in the peripheral blood of patients in the acute stage of herpes zoster

\begin{tabular}{|c|c|c|c|c|c|c|c|c|c|}
\hline Patient & Age (years) & Sex & Ly & Leu $2 \mathrm{a}^{+}$ & Leu $3 a^{+}$ & Leu $4^{+}$ & Leu $7^{+}$ & $\mathrm{MO}^{+}$ & $\mathrm{B} 1^{+}$ \\
\hline 1 & 76 & M & 1.22 & 0.31 & 0.31 & 0.60 & 0.15 & 0.24 & 0.10 \\
\hline 2 & 68 & M & 1.80 & 0.54 & 0.50 & 1.26 & 0.25 & 0.36 & 0.13 \\
\hline 3 & 58 & $\mathrm{~F}$ & 1.51 & 0.24 & 0.17 & 0.26 & 0.12 & 0.76 & ND \\
\hline 4 & 62 & M & 1.18 & 0.27 & 0.11 & 0.28 & ND & ND & ND \\
\hline 5 & 82 & $\mathrm{~F}$ & 0.60 & 0.06 & 0.28 & 0.30 & 0.08 & 0.18 & ND \\
\hline 6 & 57 & $\mathrm{M}$ & 2.10 & 0.67 & 0.84 & 1.26 & 0.25 & 0.25 & 0.21 \\
\hline 7 & 65 & $\mathrm{~F}$ & 2.03 & 0.41 & 0.91 & 0.32 & 0.12 & 0.24 & 0.16 \\
\hline 8 & 63 & M & 2.34 & 0.70 & 0.89 & 1.19 & 0.21 & 0.16 & 0.16 \\
\hline 9 & 74 & M & 2.03 & 0.57 & 0.91 & 1.42 & 0.20 & 0.49 & 0.41 \\
\hline 10 & 93 & $\mathrm{~F}$ & 0.75 & 0.20 & 0.27 & 0.35 & 0.26 & 0.29 & 0.17 \\
\hline 11 & 59 & $\mathrm{~F}$ & 1.72 & 0.53 & 0.93 & 1.00 & 0.22 & 0.86 & 0.22 \\
\hline 12 & 79 & $\mathrm{~F}$ & 0.93 & 0.22 & 0.26 & 0.46 & 0.20 & 0.47 & 0.04 \\
\hline 13 & 64 & $\mathrm{~F}$ & 1.75 & 0.39 & 0.77 & 1.37 & 0.14 & 0.39 & 0.14 \\
\hline 14 & 56 & $\mathrm{~F}$ & 2.14 & 0.06 & 0.15 & 0.26 & 0.17 & 0.00 & 0.00 \\
\hline Mean & 68 & & 1.58 & 0.37 & 0.52 & 0.81 & 0.18 & 0.36 & 0.16 \\
\hline SEM & - & & 0.15 & 0.06 & 0.09 & 0.13 & 0.02 & 0.07 & 0.03 \\
\hline
\end{tabular}

Ly, total lymphocytes; ND, not determined 
Table 3. The number $\left(10^{9}\right.$ cells/l) of lymphocytes and monocytes in the peripheral blood of patients in the reconvalescence stage of herpes zoster

\begin{tabular}{|c|c|c|c|c|c|c|c|c|c|}
\hline Patient & Age (years) & Sex & Ly & Leu $2 a^{+}$ & Leu $3 a^{+}$ & Leu $4^{+}$ & Leu $7^{+}$ & $\mathrm{MO} 2^{+}$ & $\mathrm{B} 1^{+}$ \\
\hline 1 & 76 & $\mathrm{M}$ & 1.74 & 0.66 & 0.66 & 1.17 & 0.56 & 0.89 & 0.14 \\
\hline 2 & 68 & $\mathrm{M}$ & 1.79 & 0.54 & 0.54 & 0.90 & 0.36 & 0.63 & 0.36 \\
\hline 3 & 58 & $\mathrm{~F}$ & 2.59 & 0.78 & 0.56 & 1.37 & 0.23 & 1.61 & 0.26 \\
\hline 4 & 62 & $\mathrm{M}$ & 2.62 & 0.71 & 1.32 & 1.76 & 0.05 & 0.68 & ND \\
\hline 5 & 82 & $\mathrm{~F}$ & 1.40 & 0.20 & 0.70 & 0.59 & 0.42 & 0.21 & 0.22 \\
\hline 6 & 57 & $\mathrm{M}$ & 1.73 & 0.42 & 0.73 & 1.21 & 0.24 & 0.35 & 0.17 \\
\hline 7 & 65 & $\mathrm{~F}$ & 2.70 & 0.30 & 1.27 & 1.40 & 0.41 & 0.46 & 0.73 \\
\hline 8 & 63 & $\mathrm{M}$ & 2.66 & 0.88 & 1.17 & 1.60 & 0.23 & 0.64 & 0.45 \\
\hline 9 & 74 & M & 2.95 & 0.77 & 1.30 & 1.42 & 0.59 & 1.36 & 0.59 \\
\hline 10 & 93 & $\mathrm{~F}$ & 1.37 & 0.19 & 0.48 & 0.58 & 0.27 & 0.36 & 0.30 \\
\hline 11 & 59 & $\mathrm{~F}$ & 2.98 & 0.60 & 1.43 & 1.79 & 0.30 & 0.18 & 0.45 \\
\hline 12 & 79 & $\mathrm{~F}$ & 2.37 & 0.76 & 0.43 & 1.23 & 0.59 & 0.09 & 0.33 \\
\hline 13 & 64 & $\mathrm{~F}$ & 3.14 & 1.26 & 1.38 & 2.14 & 0.44 & 0.38 & 0.25 \\
\hline 14 & 56 & $\mathrm{~F}$ & 2.05 & 0.57 & 1.03 & 1.35 & 0.29 & 0.04 & 0.74 \\
\hline Mean & 68 & & 2.29 & 0.62 & 0.94 & 1.32 & 0.38 & 0.63 & 0.41 \\
\hline SEM & - & & 0.16 & 0.08 & 0.10 & 0.12 & 0.04 & 0.13 & 0.06 \\
\hline
\end{tabular}

Ly, total lymphocytes; ND, not determined

Table 4. The number $\left(10^{9}\right.$ cells/l) of lymphocytes and monocytes in the peripheral blood of control persons

\begin{tabular}{lllllllll}
\hline & Ly & Leu $2 \mathrm{a}^{+}$ & Leu $3 \mathrm{a}^{+}$ & Leu $4^{+}$ & Leu $7^{+}$ & $\mathrm{MO} 2^{+}$ & $\mathrm{B} 1^{+}$ \\
\hline \multirow{3}{*}{ SEM } & 1.92 & 0.51 & 0.92 & 1.28 & 0.38 & 0.37 & 0.30 \\
\hline
\end{tabular}

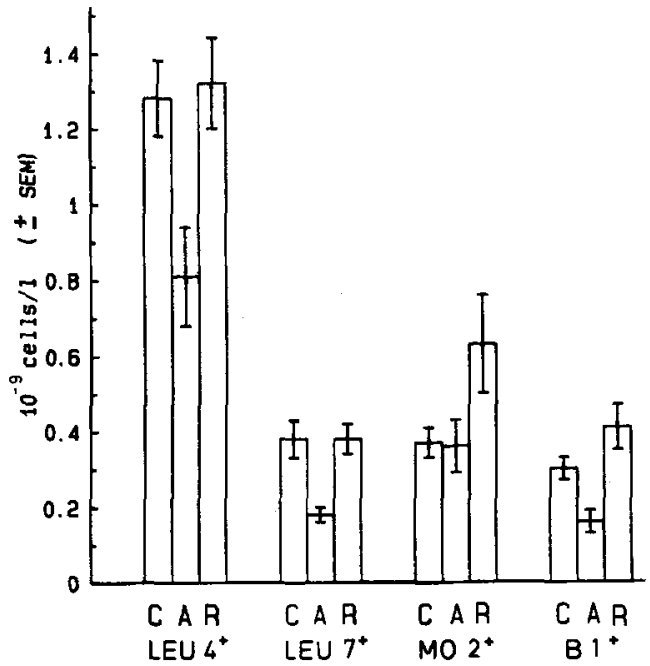

Fig. 1. Absolute numbers of Leu $4^{+}$, Leu $7^{+}, \mathrm{MO}^{+}$, and $\mathrm{B1}{ }^{+}$ cells in the acute $(A)$ and convalescent $(R)$ stage of herpes zoster and in normal controls $(C)$

$\mathrm{B}^{+}$cells increased to normal levels during convalescence (Table 3 and Fig. 1).

The mean number of HLA-DR ${ }^{+}$cells/ 1 ( \pm SEM) during the acute stage of herpes zoster infections was $0.66 \times 10^{9} \pm 0.10, \quad$ compared to convalescents

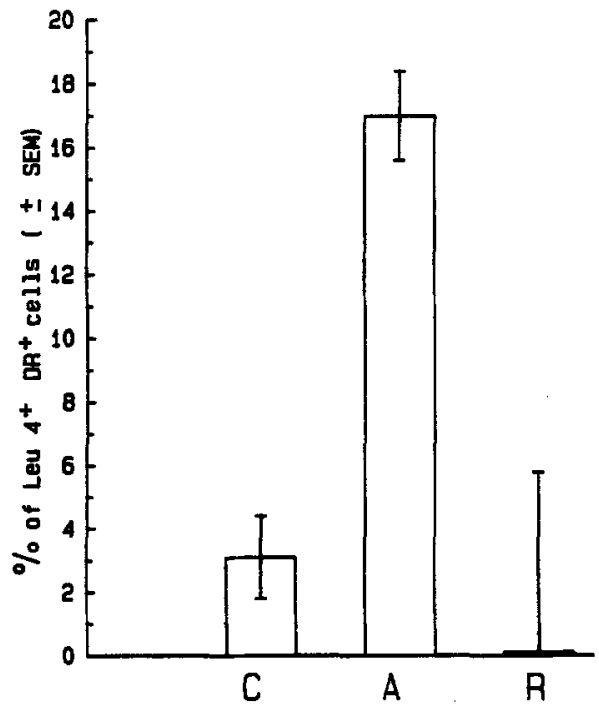

Fig. 2. Percentage of Leu $4^{+} \mathrm{DR}^{+}$cells in the acute $(A)$ and convalescent $(R)$ stage of herpes zoster and in normal controls (C)

$0.93 \times 10^{9} \pm 0.13$ and controls $0.71 \times 10^{9} \pm 0.07$. As the number of HLA-DR ${ }^{+}$cells are expressed within $\mathrm{B}^{+}, \mathrm{MO}^{+}$, and activated $\mathrm{T}$ cells, it was calculated that during the acute stage of herpes zoster a mean of $17.1 \%+1.3 \%$ of the Leu $4^{+} \mathrm{T}$ cells were activated, 
while the corresponding value for controls was $3.1 \%$ $\pm 1.4 \%$ and for convalescents $0 \% \pm 5.9 \%$ (Fig. 2 ).

\section{Skin}

The dermal and epidermal infiltrating cells consisted of Leu $2 \mathrm{a}^{+}$, Leu $3 \mathrm{a}^{+}$, and Leu $4^{+}$lymphocytes. Nearly all the cells were HLA-DR ${ }^{+}$and accordingly in an activated state. No Leu $7^{+}$cells were detected. The lymphocytes were admixed with Leu $6^{+}$Langerhans cells.

\section{Discussion}

An increase in activity and number of suppressor $\mathrm{T}$ cells is seen during acute infectious mononucleosis [5]. Similar changes in suppressor $T$ cells are seen in the acute stage of cytomegalovirus infection $[1,2]$. In the present study we found no increase in Leu $2 \mathrm{a}^{+}$ suppressor/cytotoxic $T$ cells in the acute stage of herpes zoster. However, we observed a decrease in the absolute number of Leu $4^{+} \mathrm{T}$ cells, Leu $2 \mathrm{a}^{+}$suppressor/ cytotoxic $\mathrm{T}$ cells, Leu $3 \mathrm{a}^{+}$helper/inducer $\mathrm{T}$ cells, Leu $7^{+}$killer cells, and $\mathrm{B1}^{+} \mathrm{B}$ cells. Leu $2 \mathrm{a}$ monoclonal antibody detects a common antigen present on both suppressor and cytotoxic $\mathrm{T}$ cells which explains why an increase in the number of suppressor $T$ cells may have been masked by a concomitant decrease in the number of cytotoxic $\mathrm{T}$ cells.

From experimental studies in murine models it is known that recrudescent herpes simplex type 2 lesions are associated with the generation of suppressor $T$ cells that are capable of inhibiting lymphoid cell proliferation [3]. Our findings of a decreased number of cells in various lymphocyte subsets in the acute stage of herpes zoster are in accordance with the earlier findings in the murine model. Since the balance in the number of immunoregulatory $T$ cells is a dynamic process, the observed decrease in cell numbers may have been preceded by an increase in suppressor $\mathrm{T}$ cells which in analogy to the murine model may have down-regulated the number of cells in the various lymphocyte subsets.

On the other hand it can not be ruled out that the decreased cell number within the various lymphocyte subsets is due to active recruitment and trapping of the cells in the peripheral tissue such as the skin and its draining lymph nodes.

The murine lyt $1^{+} 2^{-}$helper/inducer $\mathrm{T}$-cell population is analogous to the Leu $3 \mathrm{a}^{+}$helper/inducer T-cell population in humans and has been shown to contain the cell population for delayed type hypersensitivity
[8]. Upon this background our findings of a low number of Leu $3 \mathrm{a}^{+} \mathrm{T}$-helper/inducer cells in the acute stage of VZV infection may explain the earlier observed depressed tuberculin reaction during VZV infection. In the mice the protective cell in herpes simplex virus infection has been found to be the lyt $1^{+} 2^{-} \mathrm{T}$-helper/inducer lymphocyte [4]. In the active lesion of herpes zoster, we found that the dominating infiltrating cell subtype was the Leu $3 \mathrm{a}^{+}$T-helper/inducer cell. Thus these cell types which actively have been recruited from the peripheral blood to the skin in patients with herpes zoster seem also to be important for resolution of the infection in humans.

Normally the Leu $4^{+} \mathrm{T}$ cell in peripheral blood do not express HLA-DR class II antigens, but in the acute stage of herpes zoster a mean of $17.0 \% \pm 1.3 \%$ demonstrated HLA-DR antigens and, according to this, in a functionally activated state. Since HLA-DR ${ }^{+}$ $T$ cells can be generated in vivo by antigen challenge [9] the increased number of HLA-DR ${ }^{+} \mathrm{T}$ cells we observed was most likely induced by presentation of herpes zoster antigens to the $T$ cells. The increased level of HLA-DR expression decreased to normal during the convalescent phase. This again points to an important role for the HLA-DR ${ }^{+} \mathrm{T}$ cells in herpes zoster virus infections.

In conclusion, our findings of a decreased number of lymphocytes and killer cells during the acute stage of herpes zoster and the return to normal levels in 1 to 2 months after initial disease presentation may have implications to the acquisition of VZV infections, the immune deficiency state associated with the disease, and/or the immune response to resolve the infection.

\section{References}

1. Carney WP, Rubin RH, Hoffman RA, Hansen WP, Healey $\mathrm{K}$, Hirsch MS (1981) Analyses of $\mathrm{T}$ lymphocyte in cytomegalovirus mononucleosis. J Immunol 126:21142116

2. Crawford DH, Brickell P, Tidman N, McConnell I, Hoffbrand AV, Janossy G (1981) Increased numbers of cells with suppressor $T$ cell phenotype in the peripheral blood of patients with infectious mononucleosis. Clin Exp Immunol 43:291-297

3. Iwasaka T, Sheridan JF, Aurelian L (1983) Immunity to herpes simplex virus type 2 : recurrent lesions are associated with the induction of suppressor cells and soluble suppressor factors. Infect Immunol 42:955-964

4. Nash AA, Gell PGH (1983) Membrane phenotype of murine effector and suppressor $T$ cells involved in delayed hypersensitivity and protective immunity to herpes simplex virus. Cell Immunol 75:348-355

5. Reinherz EL, O'Brien C, Rosenthal P, Schlossman SF (1980) The cellular basis for viral-induced immunodeficiency: analysis by monoclonal antibodies. J Immunol 125:1269-1274 
6. Sorensen OLS, Haahr S, Moller-Larsen A, Wildenhoff K (1980) Cell-mediated and humoral immunity to herpes viruses during and after herpes zoster infections. Infect Immunol 29:369-375

7. Starr S, Berkovich S (1964) The depression of tuberculin reactivity during chickenpox. Pediatrics 33:769-772

8. Vadas MA, Miller JFAP, McKenzie IFC, Chism SE, Shen FW, Boyse EA, Gamble JR, Whitelaw AM (1976) Ly and Ia antigen phenotypes of $T$ cells involved in delayed type hypersensitivity and in suppression. J Exp Med 144:10-19
9. You TDY, Winchester RJ, Fu SM, Gibofsky A, Ko HS, Kunkel HG (1980) Peripheral blood Ia positive T cells: increases in certain diseases and after immunization. J Exp Med 151:91-100

Received January 8, 1987 